\title{
Inter- and intra-annual patterns of seed rain in the black spruce stands of Quebec, Canada
}

\author{
Sergio Rossi ${ }^{(1-2-3)}$, \\ Hubert Morin ${ }^{(1)}$, \\ François Gionest ${ }^{(1)}$, \\ Danielle Laprise ${ }^{(1)}$
}

\begin{abstract}
Divergent reproductive strategies of tree species generate differences in the dynamics of seed production and dispersion. The spatial and temporal variability in seed rain abundance and viability was monitored during the period 2000-2007 in four boreal stands in Quebec, Canada. The aim was to compare the inter- and intra-annual patterns of seed dispersal between species with diverging adaptive characteristics and reproductive strategies by testing the hypothesis that sympatric species can exhibit different patterns of seed dispersal according to specific ecological adaptations. The coefficient of variation (CV), representing the inter-annual variability in seed rain, was close to or higher than 1 in balsam fir (Abies balsamea [L.] P. Mill.) and white birch (Betula papyrifera Marsh.) and confirmed the mast seeding habit of the two species. In contrast, CV in black spruce (Picea mariana [Mill.] BSP) ranged between 0.24 and 0.54 , indicating a more homogeneous inter-annual amount of seed dispersal because of its semiserotinous cones that preserve seeds for an indefinite period of time. The species showed divergent intra-annual patterns of seed dispersal. Most seed dispersal of the companion species was observed in September-November, while black spruce concentrated seed rain in spring, when the proportion of germinated seeds was higher. Boreal stands experience annual seed rains constituted by a gradual dispersal of seeds of different ages and originating from cones belonging to multiple cohorts. However, asynchronous seed rains in terms of quantity and quality can occur if companion species are associated to the dominant black spruce.
\end{abstract}

Keywords: Balsam Fir, Fire, Masting, Regeneration, Reproduction, Seed Viability, Serotiny, White Birch

high latitudes (Rossi et al. 2009). The death of trees or their felling by windthrow, diseases or butt rots open the canopy by creating gaps that can be colonized by new individuals (Pham et al. 2004, Harper et al. 2006). Consequently, the maintenance or progression in species composition during stand development is related to a prompt tree recruitment after disturbance, and is influenced by the availability of advance regeneration or the seed banks (Rossi et al. 2012a).

The survival of species and the spatio-
(1) Département des Sciences Fondamentales, Université du Québec à Chicoutimi, 555 Boulevard de l'Université, Chicoutimi (QC), G7H2B1 (Canada); (2) Key Laboratory of Vegetation Restoration and Management of Degraded Ecosystems, South China Botanical Garden, Chinese Academy of Sciences, 723 Xingke Road, Tianhe District, Guangzhou 510650 (China); (3) Provincial Key Laboratory of Applied Botany, South China Botanical Garden, Chinese Academy of Sciences, 723 Xingke Road, Tianhe District, Guangzhou 510650 (China)

@ Sergio Rossi (sergio.rossi@uqac.ca)

Received: Jun 20, 2016 - Accepted: Oct 18, 2016

Citation: Rossi S, Morin H, Gionest F, Laprise D (2017). Inter- and intra-annual patterns of seed rain in the black spruce stands of Quebec, Canada. iForest 10: 189-195. - doi: 10.3832/ifor2145-009 [online 2016-12-13]

Communicated by: Gianluca Piovesan temporal composition of a plant community are closely related to the dynamics of colonization and strategies of dispersal of plant propagules. Generally, in long-living species, the investment in reproduction is not constant over time, but concentrated in episodic years with a superabundance of seeds - the mast years - which occur synchronously among trees of the same species (Kelly \& Sork 2002). The question of whether masting is a response of the physiological constraints of reserve accumulation and consumption, a reproductive strategy evolved to assure optimal fertilization of flowers and predator satiation, or the consequence of favorable environmental events remains an intriguing but still unresolved issue (Koenig \& Knops 2000, Kelly \& Sork 2002). Despite the lost opportunities for reproduction and density-dependent seedling mortality, there is a generalized convergence of tree species towards a marked periodicity in seed production (Silvertown 1980, Rossi et al. 2012b).

Species with seeds of short longevity, characterizing ecosystems where seed production is usually low or sporadic, germinate promptly after dispersal, thus reducing seed mortality and increasing the probability of recruitment of new individuals (Zasada et al. 1992, Rossi et al. 2012a). In other plant species, the capacity of germi- 
nation can be longer, thus extending the post-abscission dormancy of seeds that remain viable in the soil for years after dispersal (Qi \& Scarratt 1998, Greene et al. 1999). As a result, differences in the temporal dynamics of seed production and conservation of seed viability can be the results of divergent strategies of colonization according to the ecology of species.

In ecosystems where fires represent a chronic disturbance, and stands burn at fire return intervals compatible with seed production, some tree species have developed specialized regeneration strategies. Their seeds can be contained in serotinous cones, i.e., long term retention of seeds in the cones and canopy, which open following a fire event. Following heating, the cones release the seeds that create a new stand within a few years (Greene \& Johnson 1999, Charron \& Greene 2002). With its semiserotinous cones, black spruce (Picea mariana [Mill.] BSP) is an example of species adapted to recurrent disturbances and quick colonization under post-fire environmental conditions (Charron \& Greene 2002, Bouchard et al. 2008). Seed production of black spruce is described as periodic, with seed year masting occurring at intervals of 2-6 years (Viereck \& Johnson 1990).

In northeastern North America, the coniferous boreal forest is dominated by black spruce, whose distribution in the southern part overlaps that of balsam fir (Abies balsamea [L.] P. Mill.) and white birch (Betula papyrifera Marsh.). The characteristics of the cones of these sympatric species are different, and related to the specific dynamics of reproduction (Greene et al. 1999). Balsam fir and white birch release the seeds quickly at the end of their maturation (Rossi et al. 2012b), exhibiting a pattern of seed rain clearly divergent from that of black spruce.

We monitored the spatial and temporal variability of seed rain abundance and viability during the period 2000-2007 in four black spruce stands of the boreal forest in Quebec, Canada. Although the general dynamics of intra-annual seed rain of most boreal species are well known (Zasada et al. 1992), such observations repeated across multiple years have a valuable interest for confirming these patterns in the long run. The aim was to quantify and compare the inter- and intra-annual patterns of seed dispersal between species with diverging adaptive characteristics and colonization strategies. A hypothesis was proposed and tested that sympatric species can exhibit different patterns of seed dispersal according to specific ecological adaptations. In particular, because of its semiserotinous cones, black spruce was expected to disperse seeds according to a more homogeneous pattern within and among years than the companion species balsam fir and white birch. Seed availability is the most important factor determining establishment of tree species when they are not already present in the stands. In this work, we also assessed the propagule pressure, calculated in terms of amount of seeds, on the dominant species by companion species that are poorly present or absent from the plot.

\section{Materials and methods}

\section{Plot establishment and description}

The study was conducted in the Saguenay-Lac-Saint-Jean area (Quebec, Canada). The region has a gently rolling topography with hills reaching 500-700 $\mathrm{m}$ a.s.l. on thick and undifferentiated glacial till deposits. Four boreal stands (SIM: Simoncouche; BER: Bernatchez; MIS: Mistassibi; DAN: Camp Daniel) were identified within mature black spruce forest (Tab. 1). The region has a typical boreal climate with cold winters and cool summers. The mean annual temperature ranges between -2.1 and 0.9 ${ }^{\circ} \mathrm{C}$, while total precipitation ranges between 1006 and $1162 \mathrm{~mm}$ (Rossi 2015). The sites are characterized by long winters with the coldest temperature reaching $-44.8^{\circ} \mathrm{C}$ and a snow cover deeper than 1.5 $\mathrm{m}$ (Rossi et al. 2011). The summers are short, with the highest temperatures exceeding $29^{\circ} \mathrm{C}$ in all sites.

A permanent plot of $20 \mathrm{~m} \times 20 \mathrm{~m}$ with a buffer zone of $3 \mathrm{~m}$ was delimited in each stand by an optical prism. Twenty-five fixed points were established within the plot on a grid at intervals of $5 \mathrm{~m}$ and the location of each tree was mapped by measuring the polar distances from the predefined points, which were used as $x-y$ coordinates.

Plots contained between 52 and 86 trees, which indicated a density varying from 1300 to 2150 trees ha ${ }^{-1}$, with the densest plot being BER (Tab. 1). The stands were even-aged originated from stand replacing fires, with an age estimated of about 80140 years. The dominant height varied between 18.0 and $20.2 \mathrm{~m}$, gradually decreasing at increasing latitude. Diameter at breast height was $15.8-19.4 \mathrm{~cm}$, which produced a basal area ranging between 30.1 and $43.5 \mathrm{~m}^{2} \mathrm{ha}^{-1}$. Black spruce was the dom- inant species in all plots, representing 88$97 \%$ of trees, while balsam fir and white birch accounted for a modest percentage of the total stand basal area (Tab. 1). Mature individuals of white birches occurred in all stands, but were not present within the plots in BER, MIS and DAN (Tab. 1).

\section{Seed rain assessment}

Seed rain was measured during 20002007 using 41 seed traps per plot, of which 25 were disposed at the nodes of the grid, and 16 at the center of each grid. The seed traps were fixed to a stake at $40 \mathrm{~cm}$ above the ground and consisted of inverted galvanized steel cones with a mouth area of $4.0 \mathrm{dm}^{2}$, so that the total sampling area was $1.64 \mathrm{~m}^{2}$ per plot. Within each trap, a 0.1 $\mathrm{mm}$ mesh netting was draped to form a deep pouch, while a $12 \mathrm{~mm}$ mesh netting over the top prevented seed predators and dispersers (e.g., rodents) removing seeds from the traps. During the snow-free period, traps were emptied every 2 weeks. Data collection in winter was performed only in SIM during 2000-2005. In the other sites, there was no seed collection in winter and early spring because the stands were inaccessible.

All seeds collected were counted and identified in the lab, and the seeds of black spruce were also submitted to viability and germination tests. Seeds were spread over saturated filter papers in germination trays and maintained in a growth chamber at 30 ${ }^{\circ} \mathrm{C}$ day $/ 16{ }^{\circ} \mathrm{C}$ night, and provided with an 8 hour photoperiod (Rossi \& Bousquet 2014). The germination tests ran for a period of 21 days with weekly counts of germinated seeds. In previous tests, $85 \%$ of seeds germinated during the first 3 weeks while beyond this period germination was negligible (Rossi et al. 2012b). At the end of this period, the ungerminated seeds were cut open and analyzed. Seeds lacking the embryo and larval-infected seeds were reported as empty and insect predated, respectively. Otherwise, the embryos were excised and tested for viability in a $1 \%$ aqueous solution of tetrazolium chloride. The completely colored embryos were counted as ungerminated but viable. Viability tests were conducted only for black spruce seeds.

\section{Data analysis}

The accuracy in the estimation of seed rain was evaluated by analyzing the variation in the amount of seeds collected from

Tab. 1 - Location, number of trees, and characteristics of the four study plots of the boreal forest in Quebec, Canada.

\begin{tabular}{|c|c|c|c|c|c|c|c|c|}
\hline \multirow{2}{*}{ Stand } & \multirow{2}{*}{ Latitude } & \multirow{2}{*}{ Longitude } & \multirow{2}{*}{$\begin{array}{l}\text { Altitude } \\
\text { (m a.s.l.) }\end{array}$} & \multicolumn{3}{|c|}{ Number of trees / plot } & \multirow{2}{*}{$\begin{array}{l}\text { Stand density } \\
\left(\text { trees ha }^{-1}\right)\end{array}$} & \multirow{2}{*}{$\begin{array}{c}\text { Stand basal } \\
\text { area } \\
\left(\mathrm{m}^{2} \mathrm{ha}^{-1}\right)\end{array}$} \\
\hline & & & & Black spruce & Balsam fir & White birch & & \\
\hline SIM & $48^{\circ} 13^{\prime} \mathrm{N}$ & $71^{\circ} 15^{\prime} \mathrm{W}$ & 338 & 46 & 4 & 2 & 1300 & 30.1 \\
\hline BER & $48^{\circ} 51^{\prime} \mathrm{N}$ & $70^{\circ} 20^{\prime} \mathrm{W}$ & 611 & 84 & 2 & 0 & 2150 & 43.5 \\
\hline MIS & $49^{\circ} 43^{\prime} \mathrm{N}$ & $71^{\circ} 56^{\prime} \mathrm{W}$ & 342 & 56 & 2 & 0 & 1450 & 36.2 \\
\hline DAN & $50^{\circ} 41^{\prime} \mathrm{N}$ & $72^{\circ} 11^{\prime} \mathrm{W}$ & 487 & 52 & 3 & 0 & 1375 & 43.4 \\
\hline
\end{tabular}


each trap. For each species, the average number of traps $(n)$ required to achieve a fixed level of accuracy was calculated using the approach of determination of sample size for simple random sampling (eqn. 1):

$$
n=\frac{4 s^{2}}{\varepsilon^{2} x^{2}}
$$

where $x$ was the mean number of seeds per trap, $s$ was the estimated standard deviation for each $x, \varepsilon$ was the upper limit of the acceptable relative error, and factor 4 was a rounded value to obtain $95 \%$ confidence limits for the prediction (Snedecor \& Cochran 1980). Because of the heteroscedasticity of the variance in seed production abundances, the appropriate values of $s$ for each $x$ were estimated with log-log regressions (Mencuccini et al. 1995).

The coefficient of variation (CV) was used for analyzing the variability in seed rain between months and years. For the monthly variability, data were pooled across years. By standardizing the measure of dispersal (standard deviation) to the mean, CV allowed the variability within and between species to be efficiently compared and the intensity of the masting habit to be measured, the species showing $C V>1$ being considered as exhibiting mast-seeding (Silvertown 1980, Kelly 1994). The seeds collected from the traps in spring and summer were referenced to the seed production of the previous calendar year (Rossi et al. 2012b). $\mathrm{CV}$ were compared between species and sites using a two-way analysis of variance (ANOVA). When differences between species were significant, multiple comparisons were performed by Tukey's tests. The relationship between the seed-rain chronologies of the different species was tested using Spearman's correlations $\left(r_{s}\right)$. Data analysis and statistics were realized using $\mathrm{SAS}^{\circledast}$ (SAS Institute Inc., Cary, NC)

\section{Results}

\section{Estimate accuracy}

The variability in the number of seeds collected from traps increased exponentially at low seed productions. So a larger number of traps was required to attain the same relative error (Fig. 1). The highest variance was calculated for white birch, the species with few (SIM) or no specimens (BER, MIS, and DAN) within the studied plots, which produced the greatest relative errors. With 41 traps per plot, an acceptable error in the estimations was achieved at seed rain abundances of 400 seeds $\mathrm{m}^{-2} \mathrm{y}^{-1}$ (the lowest seed rain recorded during the study), with relative errors of less than $20 \%$ and $15 \%$ for black spruce and balsam fir, respectively. For white birch, relative errors of $20 \%$ were estimated with seed rain abundances of 650 seeds $\mathrm{m}^{-2} \mathrm{y}^{-1}$, a level of seed rain observed only in SIM for this species. For all species, higher seed rain abundance corresponded with estimations accounting lower relative errors (Fig. 1).

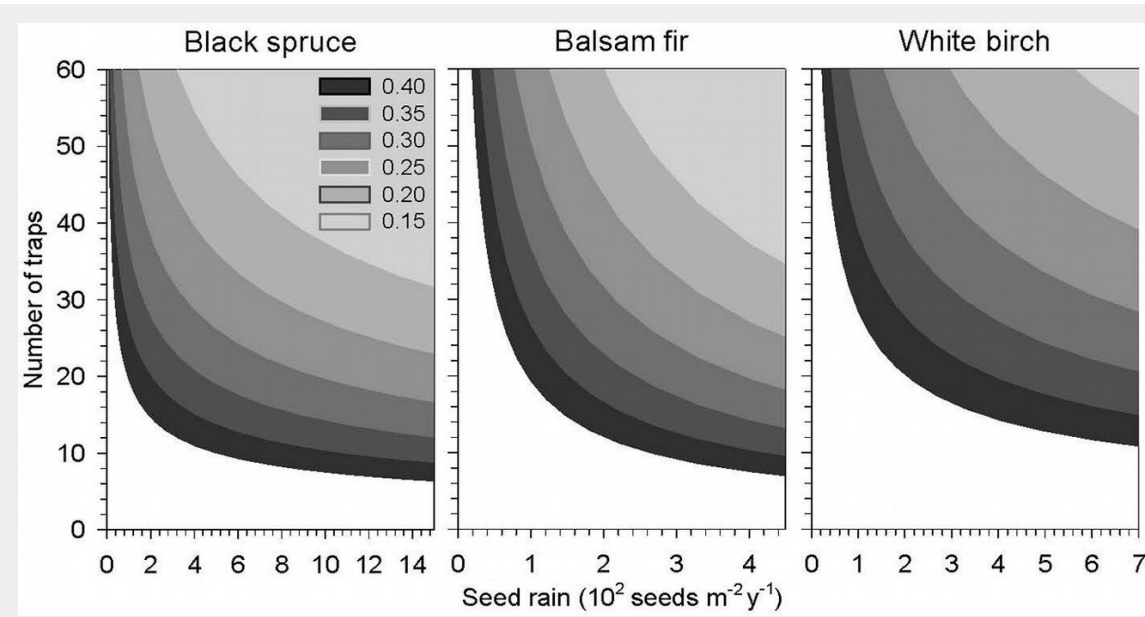

Fig. 1 - Variation in the relative error obtained with different numbers of traps in estimating seed dispersal. Areas indicate the upper limit of accepted relative error between 0.15 and 0.40 . Note the different scales of the horizontal axis for each species.

Seed rain at annual scale

Seed rain abundance varied by more than one order of magnitude among years and species, with black spruce showing the highest seed rains (Fig. 2). In MIS, seed rain

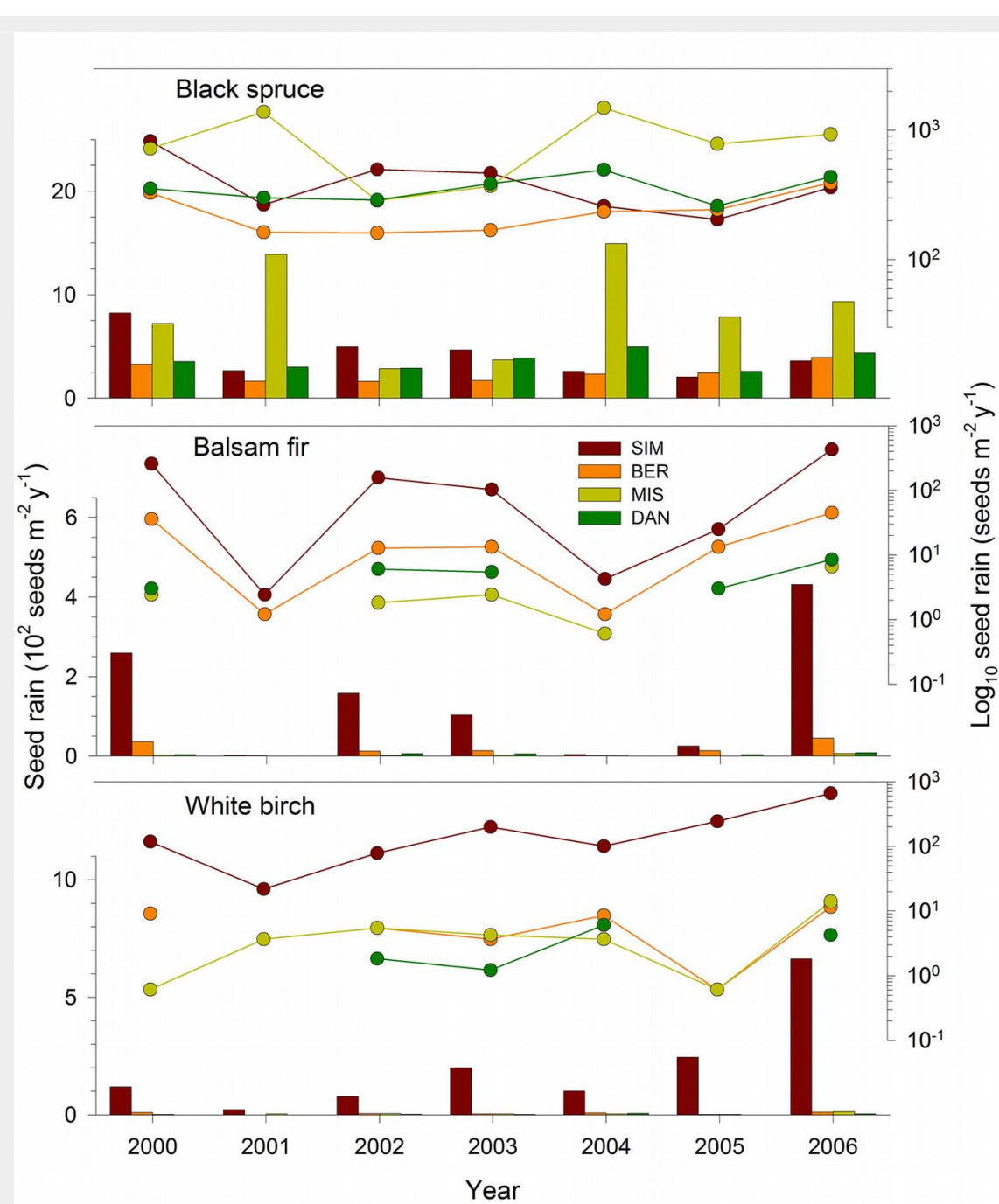

Fig. 2 - Seed rain recorded during 2000-2006 in the four study plots and reported in normal (bars) and logarithmic (lines) scale. The year 2007 is not shown because the monitoring stopped in autumn and data from the winter seed rain were lacking. Note the different normal and logarithmic axis scales for each stand. 
Tab. 2 - Coefficients of variation (CV) for the seed rain of black spruce, balsam fir and white birch calculated for the four study plots of the boreal forest in Quebec, Canada. Plant species with $\mathrm{CV}>1$ are considered to exhibit mast-seeding behavior.

\begin{tabular}{lccc}
\hline Site & Black spruce & Balsam fir & White birch \\
\hline SIM & 0.52 & 1.13 & 1.06 \\
BER & 0.37 & 0.95 & 0.79 \\
MIS & 0.54 & 1.16 & 0.98 \\
DAN & 0.24 & 0.85 & 1.25 \\
\hline
\end{tabular}

$y^{-1}$. A wide variability in seed rain was observed among sites for balsam fir and white birch, the species that were relatively uncommon or absent in the plots. Most seeds of these two companion species were collected in SIM (Fig. 2).

Black spruce showed a log-normal and right-tailed data distribution of seed rain (Fig. 3). In balsam fir and white birch, negative exponential distributions were observed, with more than $75 \%$ of values concentrated in the lower class of seed production. Over all species and sites, CV ranged between 0.24 and 1.16 (Tab. 2). ANOVA was significant $(F=8.37, p<0.05)$, and detected significant differences between species $(F=19.29, p<0.01)$, while no difference was observed between sites $(F=1.09, p>0.05)$. The lowest CVs were calculated for black spruce, with a mean value of 0.41 . On average, CV was 1.02 for both balsam fir and white birch. CV of balsam fir and white birch were close to or higher than 1 in six out of eight cases, which is associated with mast-seeding behavior. Tukey's test indicated that black spruce had an average CV statistically different from the companion species, and no difference in the average $\mathrm{CV}$ was detected between balsam fir and white birch.

The seed rains of balsam fir and white birch were significantly correlated $\left(r_{s}=0.57\right.$, $\mathrm{p}<0.001)$. No relationship was observed when correlating the seed rain of black spruce with that of balsam fir $\left(r_{s}=0.12\right.$, $p>0.05)$ or white birch $\left(r_{s}=0.14, p>0.05\right)$.

\section{Seed rain at monthly scale}

The two-way ANOVA performed at monthly scale was significant $(F=50.35$, $\mathrm{p}<0.0001)$, indicating that $\mathrm{CV}$ was different both between species $(F=112.29, p<0.0001)$ and sites $(\mathrm{F}=9.07, \mathrm{p}<0.05)$. During the snow-free period, monthly seed dispersal in black spruce was quite homogeneous, with $\mathrm{CV}$ ranging between 0.38 and 0.70 (Fig. 4). Seed dispersal in balsam fir and white birch was typically negligible during June-August, and increased dramatically in September or October in all sites. CV of the companion species confirmed the variabil-

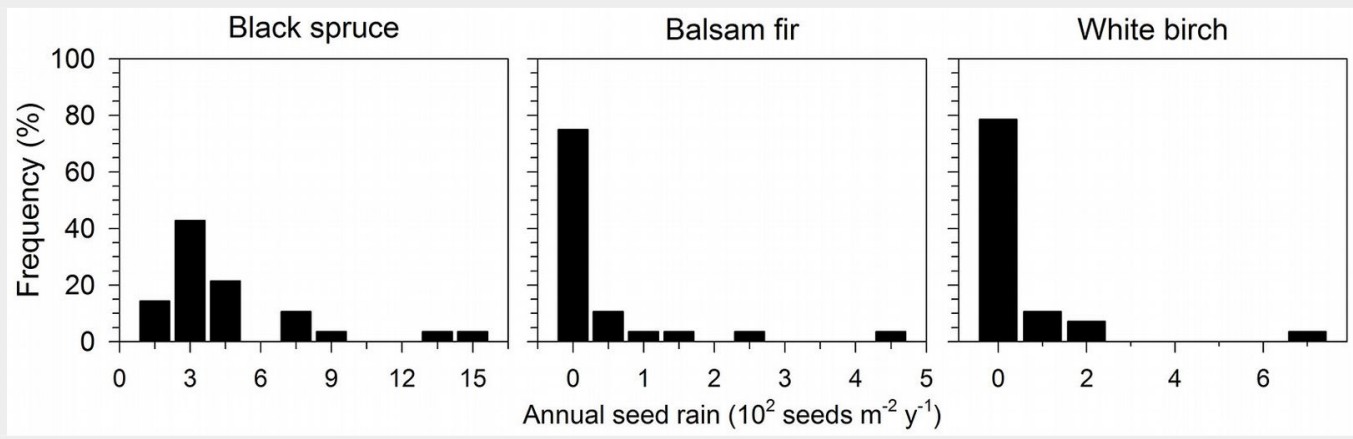

Fig. 3 - Frequency distribution of the seed rain of black spruce, balsam fir and white birch. Data represents an average of the four study plots.

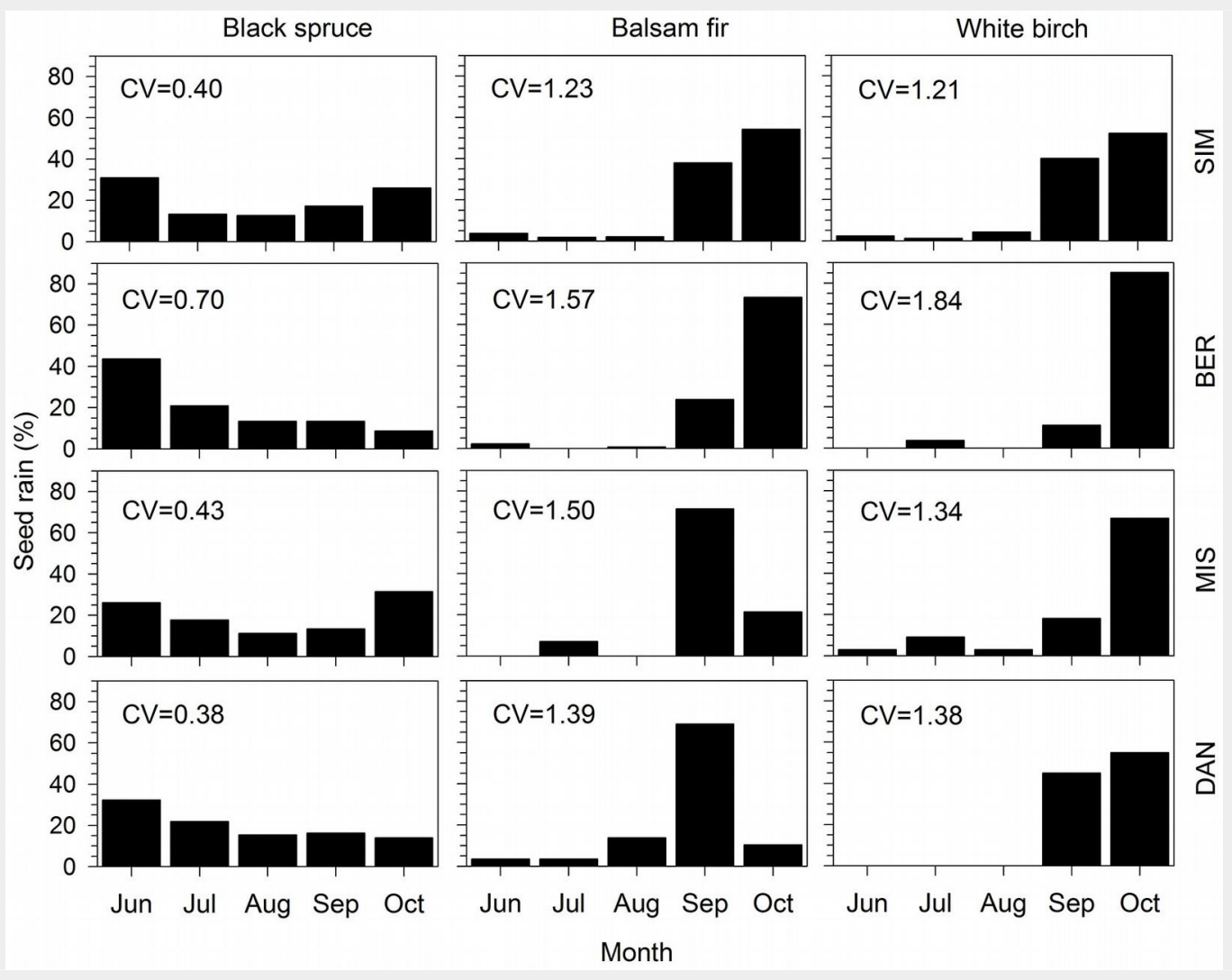


Fig. 5 - Monthly proportion of seed rain of black spruce, balsam fir and white birch in Simoncouche (SIM). CV indicates the coefficient of variation between months.

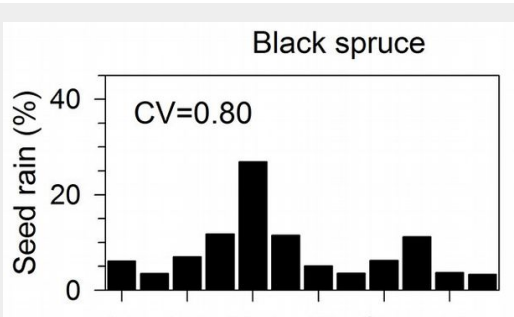

Jan Mar May Jul Sep Nov

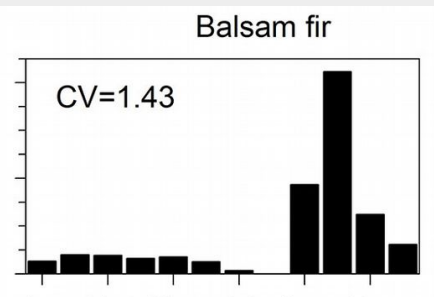

Jan Mar May Jul Sep Nov Month ity between months with values ranging between 1.21 and 1.84. Tukey's test confirmed the patterns observed at yearly scale, with the average CV of black spruce across sites being statistically different from that observed for the companion species.

The monitoring in SIM showed that most seed rain of black spruce occurred in late spring, $50.1 \%$ of seeds being collected during April-June (Fig. 5). On the contrary, between 73.3 and $81.7 \%$ of seed dispersal of the companion species was observed during September-November. For the same period, seed dispersal of black spruce represented only $21.1 \%$ of the annual seed rain (Fig. 5).

\section{Seed viability}

On average, $22.2 \%$ of black spruce seeds germinated within 28 days, although a big difference in seed viability was observed among months (Fig. 6). Most viable seeds were collected during May-September, while the seeds collected in winter (November-March) showed $20 \%$ germination or less. Only $0.4 \%$ of viable seeds remained ungerminated after the period assigned to the germination test. Insect predated (larval-infected) seeds represented $0.07 \%$ of the seed rain of black spruce (Fig. 6). Observations suggested that balsam fir, and to a lesser extent white birch, exhibited a higher proportion of seeds damaged by larvae, but the partial sampling prevented any precise estimation for the companion species (data not shown). In black spruce, dead seeds were found at proportions higher than $2 \%$ only during the first five month of the year, with a peak in March (12.9\%). Between 55.1 and $91.4 \%$ of seeds were empty across months, with an annual average of $74.0 \%$. The percentage of empty seeds had the opposite pattern to germinated seeds (Fig. 6).

\section{Discussion}

\section{Inter-annual seed rain}

This study compared seed rain abundance of black spruce, balsam fir and white birch, three sympatric species of the coniferous boreal forest in Quebec, Canada. The dataset was constituted by 8-year-long chronologies of seed rain based on samplings performed both during the snowfree period and in winter, which allowed the inter- and intra-annual dynamics of

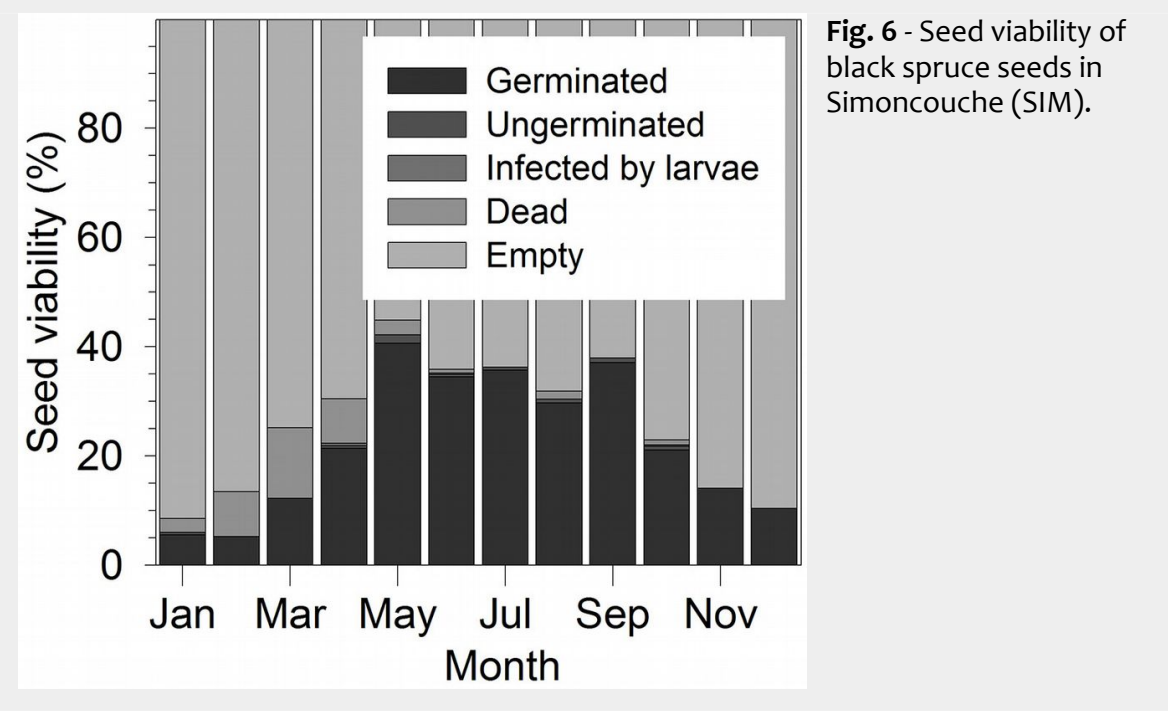

seed dispersal of the study species to be demonstrated. The different adaptations and colonization strategies of these species were expected to correspond with specific temporal patterns of seed dispersal. In all sites, seed rain abundance varied by more than one order of magnitude among years, and included some unusually large reproductive efforts. The coefficients of variation, representing the variability in seed rain among years, were close to or higher than 1 in most cases in balsam fir and white birch, and confirmed their mast seeding habit (Messaoud et al. 2007, Rossi et al. 2012b, Roland et al. 2014). In contrast, the coefficients of variation in black spruce ranged between 0.24 and 0.54 , indicating a more homogeneous inter-annual amount of seed dispersal. Black spruce also lacked the negative exponential distribution of seed rain abundance typical of mast species, showing instead a log-normal and right-tailed distribution. The hypothesis that black spruce disperses seeds according to a more homogeneous pattern among years than the companion species was accepted by our long-term monitoring.

Black spruce produces seeds contained in semiserotinous cones, whose dispersal, in absence of forest fire, is delayed or occurs over several to many years, and are preserved within the cones for an indefinite period of time (Zasada et al. 1992, Greene et al. 1999). Thus, stands dominated by black spruce experience annual seed rains constituted by a gradual dispersal of seeds of different ages and coming from cones belonging to multiple cohorts. As a consequence, the seeds dispersed annually by black spruce may belong also to the older cones and are likely to have a lower vitality than those still enclosed within the sealed cones. The well-known mast seeding habit of black spruce (Viereck \& Johnson 1990) can be demonstrated only with direct observations of cone production, and not through seed fall assessment (Haavisto et al. 1988). On the contrary, seeds of balsam fir and white birch are dispersed quickly after maturation, and produce seed rains that better reflect the wide inter-annual variation in reproductive investment of the species. The divergent patterns of seed rain observed between species with different reproductive strategies were also supported by the lack in correlation between black spruce and the two other species. The significant correlations between the seed rains of balsam fir and white birch confirmed the convergence of the dynamics of seed production (Kelly \& Sork 2002).

\section{Intra-annual seed rain}

Our long-term monitoring confirmed the general pattern of intra-annual seed rain described for the three studied species (Zasada et al. 1992). Balsam fir and white birch follow the general rule with cones and catkings opening when seeds are mature and seed dispersal distinctly peaking in autumn (Gärtner et al. 2011). For black spruce, a homogenous seed rain was expected at monthly scale. Although a part of the seeds are dispersed throughout the 
year, we reject our hypothesis because more than $50 \%$ of black spruce seeds were collected in late spring, during April-June. In this season, cycles of wetting and drying cause the scales to flex, closing and opening the cones and allowing seed dispersal to occur (Haavisto et al. 1988). Generally, the period of larger seed rain closely corresponds to that of maximum seed viability, because the heaviest and more vigorous seeds are more likely to be released by the ovoligerous scales (Skeates \& Haavisto 1995). In black spruce, the analysis of seed viability revealed a substantial increase from 5 to $40 \%$ in the proportion of germinated seeds from January to late spring. For balsam fir and white birch, previous literature showed that the viability of seeds was maximal in September-October (Rossi et al. 2012b), which coincides with the period of heaviest seed fall. These results indicate that these boreal stands can be subjected to asynchronous intra-annual seed rains in terms of both quantity and quality if companion species are associated with the dominant black spruce.

The spring dispersal of black spruce seeds may allow germination to occur when environmental conditions are favorable. This may maximize the period for growth of seedlings colonizing the forest gaps that are created after small-scale disturbances. However, the optimal conditions for seedling survival are mineral soils with thin burnt humus or organic layers of a depth less than the hypocotyl length (Hesketh et al. 2009). Thus, gaps may represent only a secondary and marginal occasion for colonization in the absence of the more appropriate regeneration niche related to postfire conditions.

\section{Seed rain and colonization strategies}

Black spruce maintains its seeds within cones that remain closed until a fire event, or gradually open over the course of several years (Farmer 1997). The multi-cohort pool of cones with viable seeds constitutes a prolonged storage considered as an aerial seed bank within the canopy (Greene et al. 1999, Viglas et al. 2013). White birch is a pioneer species, with a high capacity to disseminate huge amounts of small and light seeds, until $28.2 \times 10^{3}$ seeds $\mathrm{m}^{-2}$ year ${ }^{-1}$ in our region, which in winter are transported and spatially relocated by wind on the frozen snow (Farmer 1997, Wirth et al. 2008, Rossi et al. 2012b). The noteworthy number of seeds belonging to this species in spite of the lack of individuals within our study plots and their scarceness in the stands supported this theory. White birch bears seeds with post-abscission dormancy extending beyond nine months and germination capacity exceeding three years after dispersal, a long period compared with other boreal tree species (Greene et al. 1999, Qi \& Scarratt 1998). The relatively long-lasting germination capacity of seeds allows white birch to maintain a persistent seed bank in the soil (Zasada et al. 1992,
Ibarzabal 1994). Regeneration of balsam fir, instead, is not related to a persistent seed bank. In balsam fir, seed is a short and transient stage. In this species, seed dispersal occurs in autumn, at the end of the summer fire season. Seeds germinate quickly after dispersal, incessantly renewing the seedling banks, an advance regeneration in the understory formed by longliving, slow-growing, and shade tolerant individuals patiently waiting for release and ascendancy to the dominant layer after a canopy opening (Rossi et al. 2012a). Thus, although sharing common environments, the long-term survival of the three studied species is ensured by different reproductive mechanisms. In particular, the regeneration is delegated to specific survival strategies consisting in the establishment of persistent stages, in the form of either seed or seedlings banks, as a response to disturbances or environmental extremes (Greene et al. 1999). Moreover, the presence of a substantial amount of seeds of companion species makes the black spruce stands potentially sensitive to alternate successional trajectories in case of variations of the disturbance regimes or fire return intervals (Johnstone et al. 2010, Brown \& Johnstone 2012). In fact, although the studied forest sites were largely dominated by black spruce and the trees of companion species were infrequent or absent in some permanent plots, the seeds of balsam fir and white birch were available, constituting a relevant propagule pressure on the dominant species. Thus, shifts in the forest microclimatic conditions favoring the establishment or recruitment of other species, even if sporadic within the stand, could potentially modify the composition of these black spruce dominated stands (Boiffin \& Munson 2013).

The effect of the small proportion of balsam fir and white birch within the plots emerges by the dataset of seed rain abundance and has to be taken into account during the interpretation of the results. In some sites and years, seed production was estimated to be lower than 10 seeds $\mathrm{m}^{-2} \mathrm{y}^{-1}$, which corresponded to a collection of a total of 15 seeds by the 41 traps of a plot. In this cases, spatial dispersal processes such as wind direction and speed could play a very crucial role in affecting the measurements of seed rain and the interpretation of their inter-annual variation. Instead, the intra-annual patterns can be adequately validated by the replications among years. According to the accuracy of estimation, errors lower than 35\% were reached for seed rain abundances greater than 60 and 100 seeds $\mathrm{m}^{-2} \mathrm{y}^{-1}$ for balsam fir and white birch, respectively, and errors increased exponentially at lower seed rain abundances (Fig. 1). Despite the low seed rain abundance repeatedly recorded for these two species, the results of the coefficients of variation were in agreement between the four sites and with previous investigations. However, we are aware that the interpretations for balsam fir and white birch require additional measurements for definitely confirming the masting behavior documented in this study.

\section{Conclusions}

This study demonstrated that black spruce forests exhibit diverging patterns of seed dispersal. Black spruce, the dominant species, has a homogeneous seed dispersal. Balsam fir and white birch, the companion species, show a marked masting behavior, with seed rain abundance varying by more than one order of magnitude among years, and including some unusually large reproductive efforts. These divergence in seed rain is related to the different dynamics of reproduction of the boreal species. Despite their low presence within and around the plots, substantial amounts of seeds of the companion species were detected. Such elevated propagule pressure of other species could make the black spruce stands potentially sensitive to alternate successional trajectories in case of variations of the disturbance regimes.

\section{Acknowledgements}

This work was funded by Consortium de Recherche sur la Forêt Boréale Commerciale and Fonds de Recherche sur la Nature et les Technologies du Québec. The authors thank P.-Y. Plourde, G. Savard, A.-A. Simard, C. Simard, and A. Turcotte for technical support, and A. Garside for checking the English text.

\section{References}

Boiffin J, Munson AD (2013). Three large fire years threaten resilience of closed crown black spruce forests in eastern Canada. Ecosphere 4 (5): art56. - doi: 10.1890/ES13-00038.1

Bouchard M, Pothier D, Gauthier S (2008). Fire return intervals and tree species succession in the North Shore region of eastern Quebec. Canadian Journal of Forest Research 38: 16211633. - doi: 10.1139/X07-201

Brown CD, Johnstone JF (2012). Once burned, twice shy: repeat fires reduce seed availability and alter substrate contraints on Picea mariana regeneration. Forest Ecology and Management 266: 34-41. - doi: 10.1016/j.foreco.2011.11.006 Charron I, Greene DF (2002). Post-wildfire seedbeds and tree establishment in the southern mixedwood boreal forest. Canadian Journal of Forest Research 32: 1607-1615. - doi: 10.1139/xo2085

Farmer RE (1997). Seed ecophysiology of temperate and boreal zone forest trees. St. Lucie Press, Delray Beach, FL, USA, pp. 253. [online] URL: http://www.cabdirect.org/cabdirect/abstr act $/ 19980608084$

Gärtner SM, Lieffers VJ, Macdonald SE (2011). Ecology and management of natural regeneration of white spruce in the boreal forest. Environmental Reviews 19: 461-478. - doi: 10.1139/ a11-017

Greene DF, Johnson EA (1999). Modelling recruitment of Populus tremuloides, Pinus banksiana, and Picea mariana following fire in the mixedwood boreal forest. Canadian Journal of 
Forest Research 29: 462-473. - doi: 10.1139/x98211

Greene DF, Zasada JC, Sirois L, Kneeshaw D, Morin H, Charron I, Simard MJ (1999). A review of the regeneration dynamics of North American boreal forest tree species. Canadian Journal of Forest Research 29: 824-839. - doi: 10.1139/x98-112

Haavisto VF, Fleming RL, Skeates DA (1988). Potential and actual yields of seed from black spruce cones. Forestry Chronicle 64: 32-34. doi: 10.5558/tfc64032-1

Harper K, Bergeron Y, Drapeau P, Gauthier S, De Grandpré L (2006). Changes in spatial pattern of trees and snags during structural development in Picea mariana boreal forests. Journal of Vegetation Science 17: 535-546. - doi: 10.1111/j. 1654-1103.2006.tbo2486.x

Hesketh M, Greene DF, Pounden E (2009). Early establishment of conifer recruits in the northern Rocky Mountains as a function of postfire duff depth. Canadian Journal of Forest Research 39: 2059-2064. - doi: 10.1139/Xo9-120 Ibarzabal J (1994). Réservoir de graines des sols de sapinières boréales au nord du lac SaintJean [Seed reservoir of boreal fir stands soils north of Lac Saint-Jean]. Master thesis, Université du Québec à Chicoutimi, Chicoutimi, Canada, pp. 81. [in French] [online] URL: http:// constellation.uqac.ca/1307/1/1489797.pdf

Johnstone JF, Hollingsworth TN, Chapin III FS, Mack MC (2010). Changes in fire regime break the legacy lock on successional trajectories in Alaskan boreal forest. Global Change Biology 16: 1281-1295. - doi: 10.1111/j.1365-2486.2009.02 051.X

Kelly D (1994). The evolutionary ecology of mast seeding. Trends in Ecology and Evolution 9: 465-470. - doi: 10.1016/0169-5347(94)90310-7 Kelly D, Sork VL (2002). Mast seeding in perennial plants: why, how, where? Annual Review of Ecology and Systematics 33: 427-447. - doi: 10.1146/annurev.ecolsys.33.020602.095433

Koenig WD, Knops JMH (2000). Patterns of annual seed production by Northern Hemisphere trees: a global perspective. The Ameri- can Naturalist 155: 59-69. - doi: 10.1086/303302 Mencuccini M, Piussi P, Zanzi Sulli A (1995). Thirty years of seed production in a subalpine Norway spruce forest: patterns of temporal and spatial variation. Forest Ecology and Management 76: 109-125. - doi: 10.1016/0378-1127 (95)03555-O

Messaoud Y, Bergeron Y, Asselin H (2007). Reproductive potential of balsam fir (Abies balsamea), white spruce (Picea glauca), and black spruce ( $P$. mariana) at the ecotone between mixedwood and coniferous forests in the boreal zone of western Quebec. American Journal of Botany 94: 746-754. - doi: 10.3732/ajb.94.5. 746

Pham AT, De Grandpré L, Gauthier S, Bergeron Y (2004). Gap dynamics and replacement patterns in gaps of the northeastern boreal forest of Quebec. Canadian Journal of Forest Research 34: 353-364. - doi: 10.1139/x03-265

Qi M, Scarratt JB (1998). Effect of harvesting method on seed bank dynamics in a boreal mixedwood forest in northwestern Ontario. Canadian Journal of Botany 76: 872-883. - doi: 10.1139/b98-061

Roland CA, Schmidt JH, Johnstone JF (2014). Climate sensitivity of reproduction in a mast-seeding boreal conifer across its distributional range from lowland to treeline forests. Oecologia 174: 665-677. - doi: 10.1007/soo442-013-2821-6

Rossi S, Tremblay M-J, Morin H, Levasseur V (2009). Stand structure and dynamics of Picea mariana on the northern border of the natural closed boreal forest in Quebec, Canada. Canadian Journal of Forest Research 39: 2307-2318. doi: 10.1139/Xo9-152

Rossi S, Morin H, Deslauriers A (2011). Multi-scale influence of snowmelt on xylogenesis of black spruce. Arctic, Antarctic, and Alpine Research 43: 457-464. - doi: 10.1657/1938-4246-43-3.457 Rossi S, Morin H, Gionest F, Laprise D (2012a). Episodic recruitment of the seedling bank in balsam fir and white spruce. American Journal of Botany 99: 1-9. - doi: 10.3732/ajb.1200267 Rossi S, Morin H, Laprise D, Gionest F (2012b). Testing masting mechanisms of boreal forest species at different stand densities. Oikos 121: 665-674. - doi: 10.1111/j.1600-0706.2011.19953.x

Rossi S, Bousquet J (2014). The bud break process and its variation among local populations of boreal black spruce. Frontiers in Plant Science 5: 574. - doi: 10.3389/fpls.2014.00574

Rossi S (2015). Local adaptations and climate change: converging sensitivity of bud break in black spruce provenances. International Journal of Biometeorology 59: 827-835. - doi: 10.10 07/s00484-014-0900-y

Silvertown JW (1980). The evolutionary ecology of mast seeding in trees. Biological Journal of the Linnean Society $14: 235-250$. - doi: $10.1111 / \mathrm{j} .10$ 95-8312.1980.tbo0107.x

Skeates DA, Haavisto VF (1995). Heavier black spruce seeds produce more vigorous seedlings. Technical Note no. 31, Frontline - Forestry Research Applications, Canadian Forest Service, Sault Ste. Marie, Canada, pp. 4. [online] URL: http://www.cfs.nrcan.gc.ca/pubwarehouse/pdf s/9244.pdf

Snedecor GW, Cochran WG (1980). Statistical methods. The lowa State University Press, Ames, IA, USA, pp. 507.

Viereck LA, Johnson WF (1990). Picea mariana (Mill.) B.S.P., black spruce. In: "Silvics of North America, Vol 1: Conifers" (Burns RM, Honkala $\mathrm{BH}$ eds). USDA Forest Service, Washington, DC, USA, pp. 675.

Viglas JN, Brown CD, Johnstone JF (2013). Age and size effects on seed productivity of northern black spruce. Canadian Journal of Forest Research 43: 534-543. - doi: 10.1139/cjfr-20130022

Wirth C, Lichstein JW, Dushoff J, Chen A, Chapin III FS (2008). White spruce meets black spruce: dispersal, postfire establishment, and growth in a warming climate. Ecological Monographs 78: 489-505. - doi: 10.1890/07-0074.1

Zasada JC, Sharik TL, Nygren M (1992). The reproductive process in boreal forest trees. In: "A systems analysis of the global boreal forest" (Shugart HH, Leemans R, Bonan GB eds). Cambridge University Press, Cambridge, UK, pp. 85125. - doi: 10.1017/CBO9780511565489 